\title{
FACTORS AFFECTING THE SUCCESS OF EXCLUSIVE BREASTFEEDING AMONG BREASTFEEDING MOTHERS IN CHILD'S POLY OF DKT GUBENG POJOK HOSPITAL, SURABAYA
}

\author{
Riesmiyatiningdyah $^{1 *}$, Kusuma Wijaya Ridi Putra ${ }^{1}$, Mahfudh Jamil ${ }^{2}$ \\ ${ }^{1}$ Kerta Cendekia Nursing Academy, Sidoarjo \\ ${ }^{2}$ DKT Gubeng Pojok Hospital, Surabaya \\ *Correspondence: \\ Riesmiyatiningdyah \\ Email: miyatimiyati05@yahoo.com
}

\begin{abstract}
Background: The survival of children to grow and develop and get good care is needed to achieve a healthy generation. The success of exclusive breastfeeding in infants 0-6 months in Indonesia still does not meet expectations due to a poor knowledge of the importance Exclusive Breastfeeding and their perception of infant formula is better than breast milk. The low achievement of breastfeeding (ASI) exclusively due to several factors, namely low knowledge of the mother of the importance of breastfeeding, the sex of the baby, birth weight or premature birth, culture that does not support, families that do not support, and social change that happening in the community. Objectives: This study aimed to examine predictive factors toward the success of exclusive breastfeeding among breastfeeding mothers in Child's Poly DKT Gubeng Pojok Hospital, Surabaya.

Method: The design of this study is a cross-sectional study. The study sample was 32 breastfeeding mothers who visited at Child's Poly of DKT Gubeng Pojok Hospital, Surabaya. The variables studied were age, occupation, level of education, family support, and exclusive breastfeeding success. The results of this study were analyzed using the Stepwise Multiple Regression method with SPSS 21.

Results: Family support $(\beta=0.78, p<.001)$ were significant predictor of exclusive breastfeeding success and accounted $75.9 \%$ in the variance of exclusive breastfeeding success $\left(R^{2}=.759, F_{(4,27)}=9.18, p<.001\right)$.

Conclusion: The importance of family support in supporting the success of exclusive breastfeeding in infants 0-6 months. For this reason, health workers are expected to improve their approach to families so that they want to provide support to breastfeeding mothers.

Key words: Exclusive breastfeeding, infants 0-6 months, factors affecting, breastfeeding mothers
\end{abstract}

\section{INTRODUCTION}

The survival of children to grow and develop and get good care is needed to achieve a healthy generation. The success of exclusive breastfeeding in infants 0-6 months in Indonesia still does not meet expectations due to a poor knowledge of the importance Exclusive Breastfeeding and their perception of infant formula is better than breast milk. This is because there is no family support to breastfeed their babies and there are socio-cultural changes that occur in society, especially breastfeeding mothers because of technological advances and increasing purchasing power. Changes that occur in accordance with the nature and nature of human beings who always want to make changes (East Java Health Department, 2015).

The target achievement of infants who received exclusive breastfeeding in 2010 was $80.00 \%$ (Aprilia, 2010). According to data from the National Socio-Economic Survey (Susenas) in 2015-2016, the coverage of Exclusive ASI in Indonesia shows a decrease from $62.2 \%$ in 
2015 to $56.2 \%$ in 2016. Survey in Indonesia of families who have a role that supports breastfeeding is less than $50 \%$. The low achievement of breastfeeding (ASI) exclusively due to several factors, namely from the mother because of low knowledge of the importance of breastfeeding, in addition to baby factors include sex, birth weight or premature birth (Pantiawati, 2011; Sulistiyowati \& Siswantara, 2014). According to Rulina, other factors are cultures that do not support, families that are not supportive, and social changes that occur in the community (Briawan, 2004). It is expected that in the family can provide support to mothers to exclusively breastfeed their babies. Considering that exclusive breastfeeding has an impact on the nutritional status of children, it is necessary to support family, especially parents, which is very important in influencing the motivation, knowledge and attitudes of breastfeeding mothers.

\section{METHODS}

Study Design

The study used a cross-sectional method.

\section{Setting}

This research was conducted in the DKT Gubeng Pojok Hospital, Surabaya at June 2018.

\section{Research Subject}

The sampling technique used in this study was consecutive sampling. The study sample was 32 breastfeeding mothers who visited at Child's Poly of DKT Gubeng Pojok Hospital, Surabaya.

\section{Instrument}

This research used closed-ended questionnaires for each variable. The variables studied were age, occupation, level of education, family support, and exclusive breastfeeding success that all of which are measured using closed-ended questionnaires. The questionnaire is a questionnaire developed by researchers.

\section{Data Analysis}

The results of this study were analyzed using the Stepwise Multiple Regression method with SPSS 21 with $p \leq 0,01$. Selection of methods Stepwise Multiple Regression data analysis has passed several test requirements in the form of normality test, autocorrelation, multi-collinearity, homoscedasticity, and linearity.

\section{RESULTS}

Examination of The Influences of Age, Level of Education, Occupation, and Family Support toward Exclusive Breastfeeding Success in Child's Poly Of DKT Gubeng Pojok, Surabaya by Stepwise Multiple Regression Analysis

Table 1. Examination of the influences of age, level of education, occupation, and family support toward exclusive breastfeeding success in Child's Poly of DKT Gubeng Pojok, Surabaya by stepwise multiple regression analysis $(\mathrm{n}=32)$.

\begin{tabular}{lcccc}
\hline $\begin{array}{l}\text { Independent } \\
\text { variables }\end{array}$ & b & Beta & t & $p$-value \\
\hline Constant & 0.85 & & 1.33 & .194 \\
Family Support & 0.58 & 0.78 & 5.67 & $<.001$ \\
\hline \multicolumn{4}{r}{$R^{2}=.759, F_{(4,27)}=9.18, p<.001$} \\
\hline
\end{tabular}

From table 1, the results show that family support $(\beta=0.78, p<.001)$ was significant predictor of exclusive breastfeeding success and accounted $75.9 \%$ in the variance of exclusive breastfeeding success $\left(R^{2}=.759, F_{(4}\right.$, 27) $=9.18, p<.001)$. Age $(\beta=-0.095, p>.05)$, occupation $(\beta=-0.011, p>.05)$, and level of education $(\beta=-0.094, p>.05)$ were not significant predictors of exclusive breastfeeding success. The prediction equations were showed as follows:

1. The typical multiple regression equation based on raw score Exclusive breastfeeding success $=0.85$ +0.58 (family support).

2. The typical multiple regression equation based on $\mathrm{Z}$ score

$\mathrm{Z}_{\text {Exclusive breastfeeding success }}=0.78\left(\mathrm{Z}_{\text {Family }}\right.$ Support).

\section{DISCUSSION}

Based on the results of this study, family support was significant predictor of exclusive breastfeeding success. This shows that family support has an important role in increasing the success of exclusive breastfeeding in infants $0-6$ months. This finding was consistent with many previous studies. Family support for exclusive breastfeeding is very large, especially for the motivation, perception, emotions, and 
attitude of the breastfeeding wife. According to Krisnadi (2007), Exclusive breastfeeding does not only depend on the knowledge of the wife or the motivation of health workers, but the customs and support of family and other people nearby. Family support can also be shown by providing support in the storage of breast milk in bottles if the nursing mother is a career woman, where they have less time to meet the baby. According to Friedman, Bowden, and Jones (2010), Family support is the attitude and actions of family acceptance of family members, in the form of information support, assessment support, instrumental support and emotional support.

\section{CONCLUSION}

Based on the results of the study there are several things that can be concluded, among others:

1. Family support was significant predictor of exclusive breastfeeding success.

2. Age, occupation, and level of education were not significant predictors of exclusive breastfeeding success.

\section{SUGGESTION}

1. Health workers are expected to improve their approach to the family so that they want to provide support to breastfeeding mothers.

2. Sample in this study were limited only breastfeeding mothers who visited the Child's Poly in DKT Gubeng Pojok, Surabaya, therefore future research should replicate the study in the different setting and in the large areas.

3. This study was limited only to four factors of exclusive breastfeeding success, therefore future research should be adding other factors associated with exclusive breastfeeding success and making interventions.
Initiation Programs to Midwives in Klaten District (Doctoral dissertation, Universitas Diponegoro).

Briawan, D. (2004). Effect of formula milk promotion on shifting use of breast milk (ASI). Individual Paper Odd Semester Doctoral Program, Graduate School of $I P B$.

East Java Health Department. (2015). Monitoring Nutritional Status.

Friedman, M., Bowden, V. r., \& Jones, E. G. (2010). Family Nursing Textbook; Research, Theory \& Practice. Jakarta: EGC.

Indonesia, S. Welfare Indicators 2016.

Krisnadi, S. R. (2007). Reproduction and Contraception. Retrieved 2018 from http://www.ibuhamil.com.

Pantiawati. (2011). Infants with LBW (Low Birth Weight). Jakarta: Medical Book.

Sulistiyowati, T., \& Siswantara, P. (2014). The behavior of mothers working in providing exclusive breastfeeding in Japanan village, the working area of KemlagiMojokerto health center. Jurnal Promkes, 2(1), 89-100.

Cite This Article As: Riesmiyatiningdyah, Putra, K.W.R., Jamil, M. Factors Affecting the Success of Exclusive Breastfeeding among Breasfeeding Mothers in Child's Poly of DKT Gubeng Pojok Hospital, Surabaya. Nurse and Health: Jurnal Keperawatan 2018; 7(2): 97-99.

\section{REFERENCES}

Aprillia, Y. (2010). Analysis of the
$\begin{aligned} & \text { Socialization of Exclusive Early } \\ & \text { Breastfeeding and Breastfeeding }\end{aligned}$

